\title{
Influence of Ethylene Glycol on the Mullite Crystallization Processes Analyzed by Rietveld Refinement
}

\author{
Flaviano Willians Fernandes ${ }^{1}$, Tiago Moreira Bastos Campos ${ }^{1}$, Luciana de Simone Cividanes ${ }^{1}$,

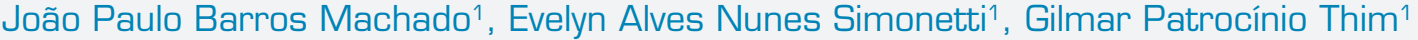

\begin{abstract}
Mullite is an excellent structural material due to its high temperature stability, high electrical insulation capabilities and creep resistance. This material has a number of technological applications, such as rocket nozzles used in the aerospace industry. In this work, mullite was obtained by sol-gel process, using silicic sol, aluminum nitrate and ethylene glycol, besides the following volume ratios of silica sol dispersion to ethylene glycol: 1/0; 1/1; $1 / 2$; and $1 / 3$. After drying, the samples were thermal treated at temperatures of 1,$000 ; 1,100 ; 1,200$ and $1,250^{\circ} \mathrm{C}$. The samples were characterized by scanning electron microscopy (SEM), X-ray diffraction (XRD) and specific surface area (Bruner-Emmett-Teller - BET). SEM showed that mullite particles are fine and nearly equiaxed. The sample without ethylene glycol showed $3 / 2$ mullite after heat treatment at $1,250^{\circ} \mathrm{C}$. The sample with intermediate ethylene glycol concentration presented two crystallization processes: the first at $1,000^{\circ} \mathrm{C}$ forming mullite and spinel phases, and the second at $1,250^{\circ} \mathrm{C}$ forming only $3 / 2$ mullite. However, the sample with the highest ethylene glycol concentration crystallized directly to mullite at $1,000^{\circ} \mathrm{C}$ with the highest yield. There is a strong dependence on the specific surface area with temperature. The Rietveld refinement showed that the a cell lattice of mullite and the $\mathrm{Al} / \mathrm{Si}$ molar ratio in the mullite formula depend on the ethylene glycol presence and on the calcination temperature. The lattice parameters $b$ and $\mathrm{c}$ are not dependent on the alumina content, but the parameter a increases with the increase in the alumina content. Samples prepared with higher ethylene glycol concentrations reached higher mullite yields at lower temperatures.
\end{abstract}

KEYWORDS: Mullite, Sol-gel, Ethylene glycol, Rietveld refinement.

\section{INTRODUCTION}

Mullite has the nominal composition of $3 \mathrm{Al}_{2} \mathrm{O}_{3} \cdot 2 \mathrm{SiO}_{2}$ (3:2 mullite) and is the only stable crystalline phase in the $\mathrm{SiO}_{2}{ }_{-}^{-}$ $\mathrm{Al}_{2} \mathrm{O}_{3}$ binary system at atmospheric pressure (Schneider et al., 2008). Mullite is known as an important material for electronic, optical and high-temperature structural applications because of its excellent properties, such as high-temperature strength, creep resistance, low thermal expansion coefficient and good dielectric properties, even at elevated temperatures and high oxidative atmosphere (Chakraborty, 2008; Cividanes et al., 2010a, 2011). Mullite has a number of technological applications, such as rocket nozzles used in the aerospace industry (Schneider et al., 2008).

The mullite structures consist of chains of distorted edge-sharing $\mathrm{Al}-\mathrm{O}$ octahedra at the corners and center of each unit cell running parallel to the $\mathrm{c}$-axis. The chains are crosslinked by $\mathrm{Si}-\mathrm{O}$ and $\mathrm{Al}-\mathrm{O}$ corner-sharing tetrahedrons. The mullite crystal system is orthorhombic - dipyramidal class (H-M Symbol 2/m 2/m 2/m); Space Group: Pbam (Schneider and Komarneni, 2005; Shackelford and Doremus, 2008). Mullite is a solid solution of silica and alumina and its stoichiometry is based on the alumina/silica molecular ratio (Campos et al., 2012; Chakraborty, 2008; Cividanes et al., 2010b; Fischer et al., 1996; Gerardin et al., 1994; Schneider et al., 2008). The chemical formula of mullite is often given by $\mathrm{Al}_{4+2 x} \mathrm{Si}_{2-2 x} \mathrm{O}_{10-x}$, where $x=0$, $x=0.25$ and $x=0.4$ correspond to sillimanite, $3: 2$ mullite and 2:1 mullite, respectively (Campos et al., 2012; Chakraborty, 2008; Cividanes et al., 2010a; Fischer et al., 1996). The amount of oxygen vacancies per unit cell is represented by $x$, which is related to the

\footnotetext{
三 1.Instituto Tecnológico de Aeronáutica - São José dos Campos/SP - Brazil

Author for correspondence: Gilmar Patrocínio Thim | Praça Marechal Eduardo Gomes, 50 - Vila das Acácias | CEP 12.228-900 São José dos Campos/SP - Brazil | Email: gpthim@gmail.com

Received: 27/08/13 | Accepted: 27/10/13
} 
replacement of silicon ions $\left(\mathrm{Si}^{4+}\right)$ by aluminum ions $\left(\mathrm{Al}^{3+}\right)$ in the tetrahedral sites of the mullite structure (Mazza et al., 2008). With increasing alumina content, the cation $\mathrm{Si}^{4+}$ is replaced by the cation $\mathrm{Al}^{3+}$ and the anion (oxygen) and the oxygen vacancies are created to maintain charge neutrality (Campos et al., 2012; Cividanes et al., 2011; Okada, 2008). In order to accommodate the structural defects, significant distortions in the aluminum and silicon polyhedra are caused. In mullite, there are three tetrahedral "chains" in the unit cell. Therefore, the distorted alumina tetrahedrons have to be arranged in an oxygen-deficient tri-cluster (three tetrahedrons sharing single corner-bridging oxygen). These clusters constitute a distinctive element of mullite crystal structure (Schneider and Komarneni, 2005; Shackelford and Doremus, 2008). Oxygen vacancies tend to cluster with short-range order along specific crystallographic directions which depend on the alumina content in mullite formula (Cividanes et al., 2010a). Moreover, oxygen vacancies tend to correlate in parallel with the lattice parameter $a$ and, in a lesser extent, with $b$, considering that mullite with lower alumina concentration tends to show more random vacancy distribution (Fischer et al., 1996; Gerardin et al., 1994; Yabuki et al., 2002). One can assume that the lattice parameter $a$ shows a linear dependence on the $\mathrm{Al}_{2} \mathrm{O}_{3}$ content (Fischer et al., 1996; Gerardin et al., 1994; Yabuki et al., 2002).

The mullite crystallization sequence depends on the homogeneity of silicon and aluminum in the precursor (Aksaf and Pask, 1975; Campos et al., 2012; Cividanes et al., 2010b; Inoue, 2004; Richardson et al., 1988). When the precursor is homogeneous, the mullite crystallization temperature is lower, and the alumina content in the mullite structure is the same of the starting material. Therefore, the control of the hydrolysis and condensation rate of the starting materials is very important to increase the precursor homogeneity (Chakraborty, 2008). Otherwise, phase segregation can occur, which not only promotes the crystallization of undesirable phases, such as $\alpha$-alumina and spinel, but also determines a higher mullitization temperature.

In the literature, many ceramic synthesis methods are described, such as: mixtures of solid reagents, coprecipitation of mixed salts, sol-gel, spray pyrolysis etc. (Cividanes et al., 2010a; Schneider et al., 1994). Depending on the application and value of the final product, each method can be justified, since each one has its peculiarity. The sol-gel process has been used for the mullite synthesis to generate products with high purity and homogeneity. In addition, it is a versatile and good reproducible method (Cividanes et al., 2010b). Moreover, the temperature required for the mullite crystallization is low $\left(1,000-1,350^{\circ} \mathrm{C}\right)$ compared to traditional methods, such as mixing of reactive powder $\left(1,500-1,700^{\circ} \mathrm{C}\right)$ as a consequence of the high homogeneity degree of the precursor (Cividanes et al., 2010b; Hong and Messing, 1998).

The tetraethylorthosilicate (TEOS) in alcoholic medium is one of the most frequently used silica source for synthesizing mullite by sol-gel (Oliveira et al., 2010; Cividanes et al., 2010b). One of the purposes of this study was the replacement of TEOS by silicic acid (aqueous medium), with the aim of reducing costs. The use of silicic acid as silica source leads to higher mullite crystallization temperature. Thus, chemical additives may be used to reduce this temperature, which can overcome the most sol-gel process shortcoming that is to control the hydrolysis and condensation reaction rates of the precursors. This difference in the reactivity of the starting materials can result in phase segregation prior to gelation process. However, the sol homogeneity level can be controlled by the action of chemical additives, such as carboxylic acids, $\beta$-diketones or functional alcohols, which act as chelating agents and modify the precursor reactivity (Brandhuber et al., 2005; Campos et al., 2012; Chakraborty, 2008; Inoue, 2004; McMahon et al., 1999; Richardson et al., 1988).

Rietveld proposed a method for refinement of crystal structures based on mathematical algorithms, which consists in comparing the experimental data obtained from $\mathrm{X}$-ray diffraction with calculated data (Rietveld, 1969). This method can be used for the unit cell refinement, crystal structure refinement, microstructure analysis, quantitative analysis of phases and determining the preferred orientation (Le Bail, 2004; Langford et al., 2000). In this work, the Rietveld refinement is used for the determination of $a, b$ and $c$ cell lattices of mullite synthesized at various temperatures. As the parameter $a$ is related to the alumina content of mullite formed, the $\mathrm{Al} / \mathrm{Si}$ molar ratio and the $x$ factor of mullite formula can be calculated.

Therefore, in this paper, mullite was obtained by sol-gel process using silicic acid and aluminum nitrite as silica and alumina precursors. Ethylene glycol was used as an agent to control the homogeneity level. The effect of ethylene glycol was analyzed by means of Rietveld refinement method.

\section{EXPERIMENTAL}

Silica sol and aluminum nitrate nonahydrate $\left(\mathrm{Al}\left(\mathrm{NO}_{3}\right)_{3} \cdot 9 \mathrm{H}_{2} \mathrm{O}\right.$; Vetec) were used as sources of silica and alumina, in molar ratio $\mathrm{Al} / \mathrm{Si}=3 / 1$. Ethylene glycol 
(Vetec) was used as a chemical additive in four volumetric proportions in relation to silica sol dispersion: $1 / 0,1 / 1,1 / 2$ and $1 / 3$, and the samples were named as S- 0, S- 1, S-2 and S-3, respectively. The procedure of obtaining silica sol and the mullite precursor gel/xerogel were described elsewhere (Campos et al., 2012). The xerogels were pre-calcined at $430^{\circ} \mathrm{C}$ (for removal of organic matter), and then were calcined at 1,$000 ; 1,100 ; 1,200$ and $1,250^{\circ} \mathrm{C}$ for 5 hours. The amounts of mullite crystallized in these samples were determined by a calibration curve constructed using the X-ray diffraction (XRD) techniques described below.

Calcined samples were analyzed by XRD, in a Philips $\mathrm{X}$-ray diffractometer, PW 1830/1840 model, using $\mathrm{CuK} \alpha$ radiation and operating at $40 \mathrm{kV}$ and $25 \mathrm{~mA}$. The XRD analysis was performed between $10^{\circ}$ and $90^{\circ}$, with a scan step time of $10.1600 \mathrm{~s}$ and with a step size of $0.0170^{\circ}$. The Rietveld refinement was performed with the data obtained from the standard reference material $\mathrm{LaB}_{6}$. This refinement led to a set of instrumental function parameters and the results are obtained by a validation method using a profile matching method. A modified pseudo-Voigt function (TCHZ) was used to fit the profiles.

A calibration curve for mullite was used to quantify the amount of crystallized mullite in the samples calcined at 1,$000 ; 1,100 ; 1,200$ and $1,250^{\circ} \mathrm{C}$. This curve is based on XRD analysis of solid mixtures of pure $\mathrm{CaF}_{2}$ and pure mullite, where $\mathrm{CaF}_{2}$ is used as internal standard. The XRD intensities at $26^{\circ}$ (related to mullite) and $28^{\circ}$ (related to $\mathrm{CaF}_{2}$ ) were determined, and the relative yield of mullite crystallization was determined according to Eq. 1:

Yield $=\frac{I_{26}}{I_{28}} \times 100$

where $I_{26}$ stands for the intensity of the XRD profile at $26^{\circ}(2 \theta)$ divided by the mass of the calcined sample and $I_{28}$ stands for the intensity of the same XRD profile at $28^{\circ}(2 \theta)$ divided by the mass of $\mathrm{CaF}_{2}$ introduced into the calcined sample.

Rietveld refinements were used to analyze the XRD data with the GSAS/EXPGUI software, and the $a, b$ and $c$ cell lattices were determined. Then, the molar concentration of alumina in the mullite $(m)$ was obtained with the linear relationship between the lattice parameter $a$ and the concentration of alumina ( $m$ ), according to Eq. 2 (Fischer et al., 1996):

$m=144.5 \times a-1029.5$
After calculating the molar concentration of alumina $(m)$, the parameter $x$ of the mullite equation $\left(A l_{4+2 x} S i_{2-2 x} O_{10-x}\right)$ was determined with the Eq. 3 (Fischer et al., 1996; Schneider et al., 2008):

$x=10-6\left[\frac{m+200}{m+100}\right]$

Then, the "concentration" of $\mathrm{Al}$ and $\mathrm{Si}$ in this material $(4+2 x$ and 2-2x, respectively) was determined. Therefore, the molar ratio $\mathrm{Al} / \mathrm{Si}$ (mullite stoichiometry) can be obtained.

Scanning electron microscopy (SEM) analyses were made using the Jeol JSM-5310 microscope, in order to observe the influence of heat treatment on the microstructure of ceramic powders. The surface area analysis of the materials calcined at 1,$000 ; 1,100 ; 1,200$ and $1,250^{\circ} \mathrm{C}$ were made by Bruner-EmmettTeller (BET) specific surface area measurements, using a Quantachrome NOVA-1200 equipment and nitrogen as the gas.

\section{RESULTS}

Figure 1 shows the X-ray diffraction of samples S-0, S-1, S-2 and S-3 calcined at 1,$000 ; 1,100 ; 1,200$ and $1,250^{\circ} \mathrm{C}$ for 5 hours. Figure 1(a) shows the crystallization of only $\alpha$-alumina after firing sample S-0 at $1,000^{\circ} \mathrm{C}$, while samples S- $1, \mathrm{~S}-2$ and S-3 formed mullite and spinel phase after firing at the same temperature. The intensities of mullite peaks at $26^{\circ}$ of the samples S-1, S-2 and S-3 are practically the same. Using these peaks as references, one can observe the decrease of the intensity in the spinel peak, in $45^{\circ}$, as the ethylene glycol (EG) content is increased. Therefore, EG should increase the homogeneity of mullite precursors and should make it possible to mullite crystallizes at $1,000^{\circ} \mathrm{C}$, which is the mullite crystallization temperature of single phase precursor (the most homogeneous one). This increase in the homogeneity was observed in a previous work of our research group (Campos et al., 2012). This work showed, using images of a scanning electronic microscope with energy dispersive X-ray (EDXelemental mapping), that the samples prepared with EG are constituted by silicon and aluminum particles whose sizes are much smaller than those present in the sample prepared without EG. This previous work (Campos et al., 2012) also showed that the $\mathrm{Al}(\mathrm{IV})$ and $\mathrm{Al}(\mathrm{V})$ contents in the mullite precursors can be a decisive factor for crystallizing mullite at $1,000^{\circ} \mathrm{C}$. 


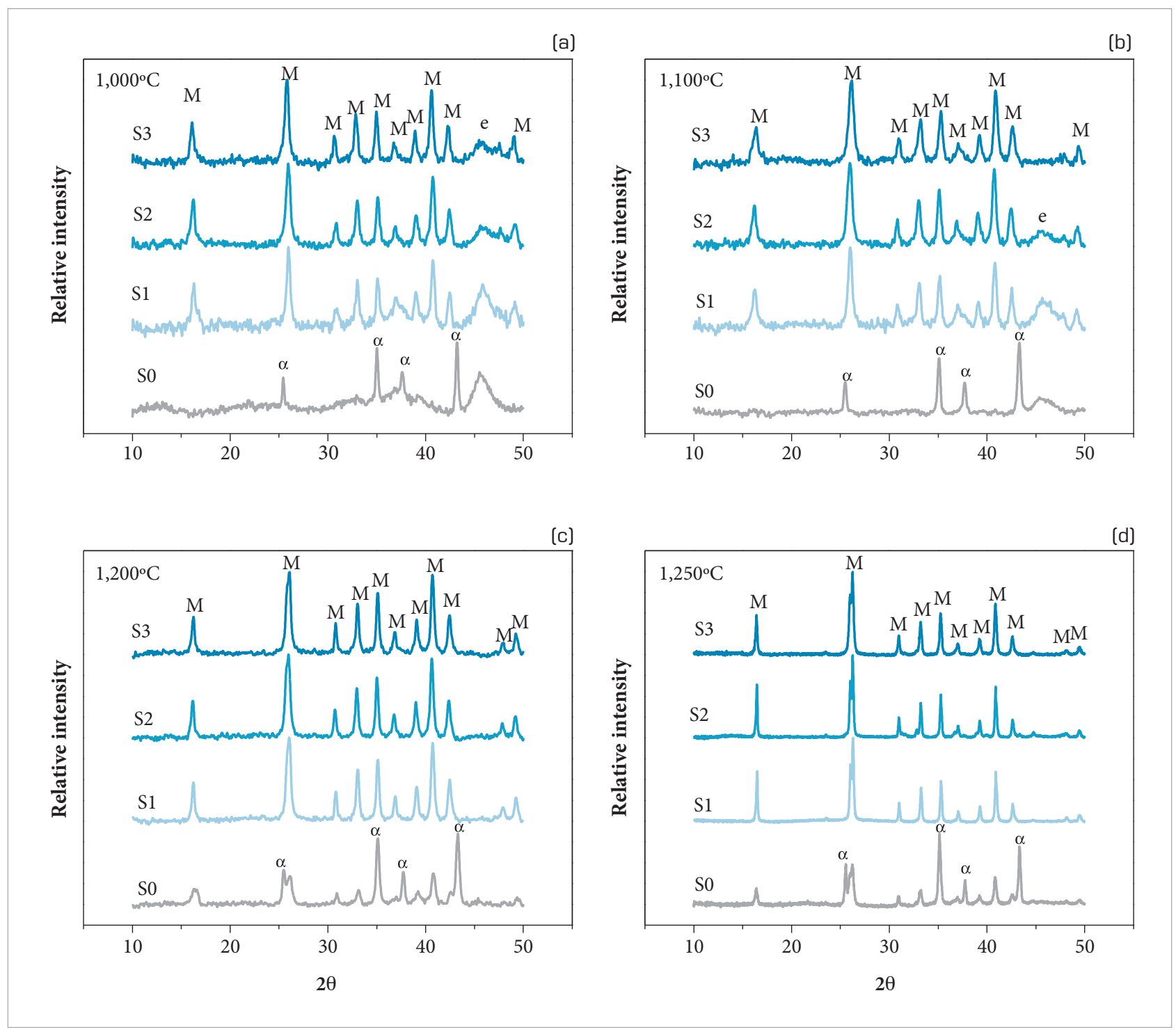

Figure 1. X-ray diffraction patterns of samples S-O, S-1, S-2 and S-3 calcined for 5 hours at: (a) $1,000^{\circ} \mathrm{C}$; (b) $1,100^{\circ} \mathrm{C}$; (c) $1,200^{\circ} \mathrm{C}$ and (d) $1,250^{\circ} \mathrm{C}$; M: mullite; e: spinel; $\alpha$ : $\alpha$-alumina.

Sample without EG had low contents of aluminum with these coordinations (Campos et al., 2012).

Figure 1(b) shows that $\alpha$-alumina is still the only crystalline phase in the sample S-0 and samples prepared with EG crystallized mullite. Figure 1 also shows that the sample with the highest EG concentration, S-3, did not show the presence of spinel phase, but the other two samples prepared with EG did.

Figure 1(c) shows the disappearance of the spinel phase in all samples fired at $1,200^{\circ} \mathrm{C}$ and the formation of mullite phase. Thus, mullite was formed by consumption of spinel. One can still observe that while the samples S-1, S-2 and S-3 formed only mullite at $1,200^{\circ} \mathrm{C}$, the sample $\mathrm{S}-0$ formed mullite and $\alpha$-alumina. Mullite could be obtained from sample S-3 at $1,200^{\circ} \mathrm{C}$, which is close to the crystallization temperature for mullite obtained from TEOS (Oliveira et al., 2010; Ban et al., 1996). Figure 1(d) shows the mullite formation in all samples calcined at $1,250^{\circ} \mathrm{C}$, but sample S- 0 continues to form the $\alpha$-alumina phase together with mullite phase.

Table 1 shows the parameters obtained from Rietveld refinements for mullite crystallization at $1,000^{\circ} \mathrm{C}$. There are no data for sample S-0 since mullite did not crystallized at this temperature from this sample. One can see that sample S-1 crystallized mullite with the major percentage of alumina (70\%) and samples S-2 and S-3 show practically the same percentage $(\sim 67 \%)$. However, the mullite yield 
is quite different between the samples, where the sample prepared with the highest EG concentration showed the highest yield (52\%), while the sample prepared with the lowest EG concentration showed the lowest mullite yield (35\%). The cell parameters $b$ and $c$ do not depend on the alumina content in the mullite formula, as reported in the literature. Therefore, they are virtually constant in all experiments. The parameter $a$ determined for mullite from all samples is very similar too.

It is important to note that the alumina content showed in Table 1 is the $\mathrm{Al}_{2} \mathrm{O}_{3}$ molar content that is present in the mullite structure, according to the chemical formula of mullite: $A l_{4+2 \mathrm{x}} \mathrm{Si}_{2-2 \mathrm{x}} \mathrm{O}_{10-\mathrm{x}}$. In this table, $3 / 2$ mullite has $60 \%$ of $\mathrm{Al}_{2} \mathrm{O}_{3}$ molar content, and $2 / 1$ mullite has $67 \%$.

Table 2 shows that alumina contents in all samples treated at $1,100^{\circ} \mathrm{C}$ are lower than that treated at $1,000^{\circ} \mathrm{C}$. Therefore, samples were initially rich in alumina and the thermal treatment at $1,100^{\circ} \mathrm{C}$ provoked the incorporation of silica into mullite formula. Samples prepared with higher concentration of EG lead to mullite with higher contents of alumina and higher crystallization yields. The lattice parameters $b$ and $c$ are not depended on the alumina content, but the parameter $a$ increases with the increase of alumina content.

Table 3 shows that S- 0 crystallized mullite with $53 \%$ of alumina, while all samples prepared with EG reach alumina contents closer to mullite $3 / 2$ (64\%). However, mullite at this temperature prepared from all samples with EG always formed mullite with virtually the same value of alumina content. One can conclude that the alumina content of mullite depends on the presence of EG, but does not depend on its concentration. However, the mullite yield is strongly dependent on the EG concentration. Samples prepared with higher EG concentration showed higher yield than samples prepared with lower concentration.

Table 4 shows that at $1,250^{\circ} \mathrm{C}$ all samples crystallize mullite with composition near to $\mathrm{Al} / \mathrm{Si}=3 / 2$ and all samples that

Table 1. Mullite crystallization for samples calcined at $1,000^{\circ} \mathrm{C}$

\begin{tabular}{|c|c|c|c|c|c|c|}
\hline Sample & $\mathrm{Al}_{2} \mathrm{O}_{3}(\% \mathrm{~mol})$ & $x$ & Yield (\%) & $a$ [A] & $b$ [Å] & $c(\AA)$ \\
\hline S-1 & $70 \pm 2$ & $0.48 \pm 0.08$ & $35 \pm 4$ & $7.61 \pm 0.01$ & $7.72 \pm 0.01$ & $2.891 \pm 0.003$ \\
\hline S-2 & $67 \pm 2$ & $0.41 \pm 0.08$ & $40 \pm 4$ & $7.58 \pm 0.01$ & $7.72 \pm 0.01$ & $2.888 \pm 0.002$ \\
\hline S-3 & $68 \pm 2$ & $0.43 \pm 0.08$ & $52 \pm 4$ & $7.59 \pm 0.01$ & $7.72 \pm 0.01$ & $2.890 \pm 0.002$ \\
\hline
\end{tabular}

Table 2. Mullite crystallization for samples calcined at $1,100^{\circ} \mathrm{C}$.

\begin{tabular}{|c|c|c|c|c|c|c|}
\hline Sample & $\mathrm{Al}_{2} \mathrm{O}_{3}(\% \mathrm{~mol})$ & $x$ & Yield [\%] & $a(\dot{A})$ & $b(\AA)$ & $G(\AA)$ \\
\hline S-1 & $62 \pm 2$ & $0.29 \pm 0.08$ & $37 \pm 4$ & $7.552 \pm 0.007$ & $7.675 \pm 0.005$ & $2.879 \pm 0.001$ \\
\hline S-2 & $64 \pm 2$ & $0.34 \pm 0.08$ & $51 \pm 4$ & $7.568 \pm 0.005$ & $7.693 \pm 0.003$ & $2.887 \pm 0.001$ \\
\hline S-3 & $67 \pm 2$ & $0.41 \pm 0.08$ & $62 \pm 4$ & $7.589 \pm 0.006$ & $7.673 \pm 0.003$ & $2.884 \pm 0.001$ \\
\hline
\end{tabular}

Table 3. Mullite crystallization for samples calcined at $1,200^{\circ} \mathrm{C}$.

\begin{tabular}{|c|c|c|c|c|c|c|}
\hline Sample & $\mathrm{Al}_{2} \mathbf{O}_{3}(\% \mathrm{~mol})$ & $x$ & Yield (\%) & $a(\dot{A})$ & $b(\mathbf{A})$ & $G(\AA)$ \\
\hline S-0 & $53 \pm 2$ & $0.1 \pm 0.1$ & $41 \pm 4$ & $7.493 \pm 0.008$ & $7.687 \pm 0.007$ & $2.872 \pm 0.002$ \\
\hline S-1 & $64 \pm 2$ & $0.33 \pm 0.08$ & $69 \pm 4$ & $7.563 \pm 0.002$ & $7.690 \pm 0.002$ & $2.8885 \pm 0.0007$ \\
\hline S-2 & $64 \pm 2$ & $0.35 \pm 0.08$ & $81 \pm 4$ & $7.568 \pm 0.003$ & $7.700 \pm 0.002$ & $2.8877 \pm 0.0007$ \\
\hline$S-3$ & $65 \pm 2$ & $0.36 \pm 0.08$ & $90 \pm 4$ & $7.575 \pm 0.003$ & $7.699 \pm 0.003$ & $2.8891 \pm 0.0008$ \\
\hline
\end{tabular}

Table 4. Mullite crystallization for samples calcined at $1,250^{\circ} \mathrm{C}$.

\begin{tabular}{|c|c|c|c|c|c|c|}
\hline Sample & $\mathrm{Al}_{2} \mathbf{O}_{3}(\% \mathrm{~mol})$ & $x$ & Yield [\%] & $a(\AA)$ & $b$ [Å] & $c(\AA)$ \\
\hline$S-0$ & $63 \pm 2$ & $0.32 \pm 0.08$ & $66 \pm 4$ & $7.560 \pm 0.004$ & $7.696 \pm 0.004$ & $2.886 \pm 0.001$ \\
\hline S-1 & $65 \pm 2$ & $0.36 \pm 0.07$ & $100 \pm 4$ & $7.571 \pm 0.001$ & $7.696 \pm 0.001$ & $2.8886 \pm 0.0002$ \\
\hline S-2 & $65 \pm 2$ & $0.36 \pm 0.07$ & $100 \pm 4$ & $7.572 \pm 0.001$ & $7.691 \pm 0.001$ & $2.8878 \pm 0.0003$ \\
\hline S-3 & $64 \pm 2$ & $0.33 \pm 0.07$ & $100 \pm 4$ & $7.563 \pm 0.001$ & $7.695 \pm 0.01$ & $2.8869 \pm 0.0003$ \\
\hline
\end{tabular}


were prepared with EG reached a yield of $100 \%$, while the sample prepared without EG reached a yield of $66 \%$. All cell lattices are practically the same in the mullite crystallized at this temperature.

Schneider and Komarneni (2005) showed the influence of the $\mathrm{Al}_{2} \mathrm{O}_{3}$ content of mullite ceramics on the mechanical properties of the material. They showed that $3 / 2$ mullite (60 mol $\% \mathrm{Al}_{2} \mathrm{O}_{3}$ ) has about $380 \mathrm{MPa}$ of bending strength at $1,300^{\circ} \mathrm{C}$ in air, while $2 / 1$ mullite $\left(67 \mathrm{~mol} \% \mathrm{Al}_{2} \mathrm{O}_{3}\right)$ has about $240 \mathrm{MPa}$ at the same conditions. They also showed that $3 / 2$ mullite has about 3.4 MPa.m $\mathrm{m}^{1 / 2}$ of fracture toughness and 2/1 mullite has about 2.4 MPa. $\mathrm{m}^{1 / 2}$, both at $1,300^{\circ} \mathrm{C}$ in air. Therefore, one can conclude that $3 / 2$ mullite shows better mechanical properties than $2 / 1$ mullite, which can increase the life time and the reliability of the $3 / 2$ mullite-based pieces for using in aerospace applications. The $2 / 1$ mullite-based pieces can fail during application in a shorter time than $3 / 2$ mullite, because of the $\mathrm{Al}_{2} \mathrm{O}_{3}$ content. Therefore, Rietveld method can be used as an analytical tool to ensure that the alumina content would not interfere with the mullite properties, since it can determine a cell lattice of mullite and this parameter is related to alumina content.

The results obtained by BET for samples S-0, S- 1, S-2 and $\mathrm{S}-3$ calcined at 1,000 and $1,200^{\circ} \mathrm{C}$ are shown in Table 5 . Samples S-1, S-2 and S-3 show higher surface area than S-0 when they were fired at $1,000^{\circ} \mathrm{C}$. However, these surface areas are practically the same after firing at $1,200^{\circ} \mathrm{C}$, since the surface area of samples S-1, S-2 and S-3 decreased substantially when they were fired at $1,200^{\circ} \mathrm{C}$. These results can be correlated to the results previously expressed in Tables 1 to 4 , which showed that EG increased the homogeneity of the mullite precursors, accelerating the incorporation of silica into mullite formula, decreasing the alumina contents or increasing the mullite yield. EG molecules should act during the sol-gel stage decreasing the polymerization kinetics of silica, resulting in small silica clusters. These small silica clusters may be more homogeneously mixed with those of alumina. Single phase mullite gels are very homogeneous because they have aluminum and silicon mixed in an atomic level.

Therefore, EG increases the homogeneity of the precursor, favoring the overall mullite kinetics. The higher surface area of the samples prepared with EG calcined at $1,000^{\circ} \mathrm{C}$ should be correlated with the homogeneity of these samples.
Campos et al. (2012) also showed that samples prepared with EG were constituted by silicon and aluminum particles whose sizes are much smaller than those present in the sample prepared without EG. Samples prepared with EG also showed good homogeneity, since they crystallizes mullite in lower temperatures compared to the sample prepared without EG.

Figure 2 shows the SEM micrographs of samples S-0, S- 1 and S-3 calcined at $1,000^{\circ} \mathrm{C}$ for 5 hours (Fig. $2 \mathrm{a}$, b and c, respectively) and $1,250^{\circ} \mathrm{C}$ for 5 hours (Fig. $2 \mathrm{~d}$, e and f, respectively). SEM micrograph of sample S-2 is not shown because it was very similar to the samples S-1 and S-3.

It can be seen from the images, and in agreement with the BET results, that samples with the same EG/silanol volumetric proportion and calcined at $1,000^{\circ} \mathrm{C}$ present smaller particles compared to samples calcined at $1,250^{\circ} \mathrm{C}$. Furthermore, for both temperatures $\left(1,000\right.$ and $\left.1,250^{\circ} \mathrm{C}\right)$, it is clear that S-0 sample presents particles with irregular shapes and samples S-1 and S-3 contain particles with near-angular shapes. This changing in the morphology of the particles is explained by the changing in the phases (from $\alpha$-alumina to mullite, or from mullite with different alumina contents) present in the samples.

Table 5. Effect of heat treatment on mullite amount and surface area.

\begin{tabular}{|c|c|c|c|}
\hline \multicolumn{4}{|c|}{$1,000^{\circ} \mathrm{C}$} \\
\hline Sample & $\begin{array}{c}\mathrm{Al}_{2} \mathbf{O}_{3} \\
\text { content }\end{array}$ & $\begin{array}{c}\text { Yield \% } \\
\text { [mol/mol] }\end{array}$ & $\begin{array}{l}\text { Surface area } \\
\qquad\left(\mathrm{m}^{2} / \mathrm{g}\right)\end{array}$ \\
\hline$S-0$ & - & - & 17 \\
\hline S-1 & 70 & 35 & 30 \\
\hline S-2 & 67 & 40 & 30 \\
\hline S-3 & 68 & 52 & 31 \\
\hline \multicolumn{4}{|c|}{$1,200^{\circ} \mathrm{C}$} \\
\hline Sample & $\begin{array}{c}\mathrm{Al}_{2} \mathrm{O}_{3} \\
\text { content }\end{array}$ & $\begin{array}{c}\text { Yield \% } \\
\text { [mol/mol] }\end{array}$ & $\begin{array}{l}\text { Surface area } \\
\qquad\left(\mathrm{m}^{2} / \mathrm{g}\right]\end{array}$ \\
\hline S-0 & 53 & 41 & 6 \\
\hline S-1 & 64 & 69 & 7 \\
\hline S-2 & 64 & 81 & 10 \\
\hline S-3 & 65 & 90 & 10 \\
\hline
\end{tabular}




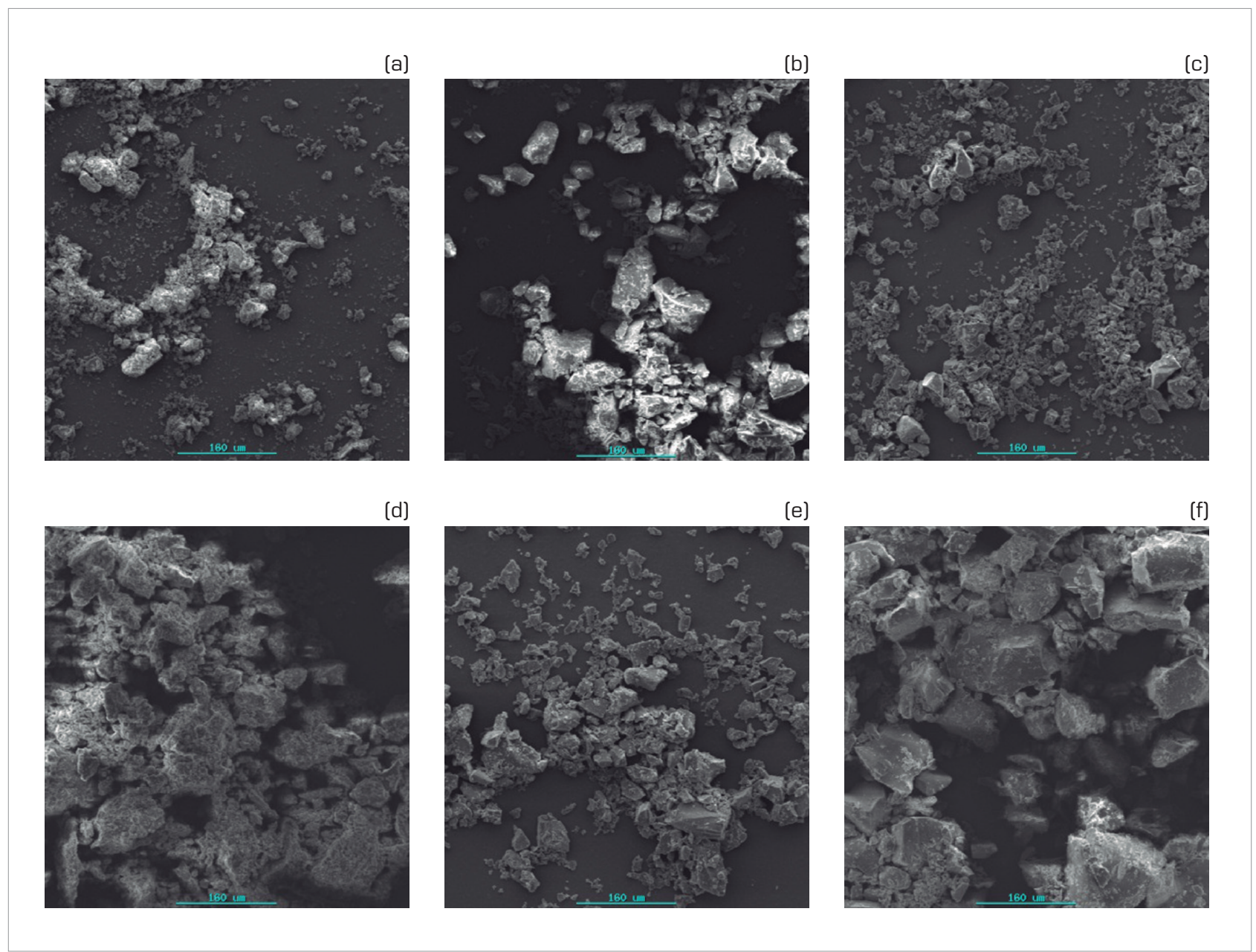

Figure 2. Scanning electron microscopy micrographs of samples S-0, S-1 and S-3 calcined at: 1,000 $\mathrm{C}$ for 5 hours la, b and c, respectively] and $1,250^{\circ} \mathrm{C}$ for 5 hours [d, e and $\mathrm{f}$, respectively].

\section{CONCLUSIONS}

EG has a positive effect in the crystallization of mullite, with the suppression of undesirable phases like $\alpha$-alumina. The experimental methodology used here showed to be effective for obtaining mullite powder with fine particles, and in the temperature near $1,200^{\circ} \mathrm{C}$ (near the crystallization temperature when using TEOS as precursor), with a lower cost than the methods that use TEOS as silica source. These fine powders have adequate characteristics to be applied in the sintering process of heat insulation or heat exchanges parts.

The X-ray analysis and the Rietveld refinement showed that a cell lattice of mullite and the Al/Si molar ratio in the mullite formula depend on the presence of EG and on the calcination temperature. However, different EG concentrations influence the $a$ cell lattice virtually in the same way. The samples prepared with higher concentration of EG lead to mullite with higher crystallization yields at lower temperatures.

The Rietveld method showed to be efficient to analyze the $\mathrm{Al}_{2} \mathrm{O}_{3}$ content in the mullite, which is associated to the mechanical properties of mullite. Then, this method can be used to ensure that the mullite ceramics will not fail during aerospace application.

\section{ACKNOWLEDGMENTS}

The authors gratefully acknowledge CNPq, FAPESP and CAPES for financial support. 


\section{REFERENCES}

Aksaf, İ.A.and Pask, J.A., 1975, "Stable and Metastable Equilibria in the System $\mathrm{SiO}_{2}-\mathrm{Al}_{2} \mathrm{O}_{3}$, Journal of the American Ceramic Society, Vol. 58, No. 11-12, pp. 507-512. doi: 10.1111/j.1151-2916.1975. tb18770.x

Ban, T., Hayashi, S., Yasumori, A., and Okada, K., 1996, "Characterization of Low Temperature Mullitization", Journal of the European Ceramic Society, Vol. 16, No. 2, pp. 127-132. doi: 10.1016/0955-2219(95)00131-X

Brandhuber, D., Torma, V., Raab, C., Peterlik, H., Kulak, A., and Hu, N., 2005, "Glycol-Modified Silanes in the Synthesis of Mesoscopically Organized Silica Monoliths with Hierarchical Porosity", Chemistry of Materials, Vol. 17, No. 16, pp. 4262-4271. doi: 10.1021/ $\mathrm{cm048483j}$

Campos, T.M.B., Cividanes, L.S., Brunelli, D.D., Sakane, K.K. and Thim, G.P., 2012, "Effect of ethylene glycol on the mullite crystallization", Journal of the European Ceramic Society, Vol. 32, No. 4, pp. 835-842. doi: 10.1016/j.jeurceramsoc.2011.09.028

Chakraborty, A.K., 2008, "Si-incorporated alumina phases formed out of diphasic mullite gels", Journal of Materials Science, Vol. 43, No. 15, pp. 5313-5324. doi: 10.1007/s10853-008-2775-y

Cividanes, L.S, Brunelli, D.D., Bertran, C.A., Campos, T.M.B., and Thim, G.P., 2011, "Urea effect on the mechanism of mullite crystallization", Journal of Materials Science, Vol. 46, No. 23, pp. 7384-7392. doi: 10.1007/s10853-011-5699-x

Cividanes, L.S, Campos, T.M.B., Rodrigues, L.A., Brunelli, D.D., and Thim, G.P., 2010a, "Review of mullite synthesis routes by sol-gel method", Journal of Sol-Gel Science and Technology, Vol. 55, No. 1, pp. 111-125. doi: 10.1007/s10971-010-2222-9

Cividanes, L.S, Campos, T.M.B., Bertran, C.A., Brunelli, D.D., and Thim, G.P., 2010b, "Effect of urea on the mullite crystallization", Journal of Non-Crystalline Solids, Vol. 356, No. 52-54, pp. 30133018. doi: 10.1016/j.jnoncrysol.2010.05.076

Fischer, R.X., Schneider, H. and Voll, D., 1996, "Formation of Aluminum Rich 9:1 Mullite and its Transformation to Low Alumina Mullite upon Heating", Journal of the European Ceramic Society, Vol. 16, No.2, pp. 109-113.

Gerardin, C., Sundaresan, S., Benziger, J., and Navrotsky, A., 1994, "Structural Investigation and Energetics of Mullite Formation from SolGel Precursors", Chemistry of Materials, Vol. 6, No. 2, pp 160-170. doi: $10.1021 / \mathrm{cm00038a011}$

Hong, S.H. and Messing, G.L., 1998, "Anisotropic Grain Growth in Diphasic-Gel-Derived Titania-Doped Mullite", Journal of the American Ceramic Society, Vol. 81, No. 5, pp. 1269-1277. doi: 10.1111/ j.1151-2916.1998.tb02478.x

Inoue, M., 2004, "Glycothermal synthesis of metal oxides", Journal of Physics: Condensed Matter, Vol. 16, No. 14, pp. S1291-S1303. doi:10.1088/0953-8984/16/14/042
Langford, J., Louër, D. and Scardi, P., 2000, "Effect of a Crystallite Size Distribution on X-ray Diffraction Line Profiles and Whole-powderpattern Fitting", Journal of Applied Crystallography, Vol. 33, No. 2, pp. 964-974. doi: 10.1107/S002188980000460X

Le Bail, A., 2004, "Monte Carlo Indexing with McMaille", Powder Diffraction, Vol. 19, No. 3, pp. 249-254. doi: 10.1154/1.1763152

Mazza, D., Ronchetti, S., and Costanzo, A., 2008, "Atomistic simulations on mullite $\mathrm{Al}_{2}\left[\mathrm{Al}_{2+2 x} \mathrm{Si}_{2-2 x}\right] \mathrm{O}_{10-x}$ in a variable range of composition", Journal of the European Ceramic Society, Vol. 28, No. 2, pp. 367-370. doi: 10.1016/j.jeurceramsoc.2007.03.003

McMahon, C.N., Alemany, L., Callender, R.L., Bott, S.G. and Barron, A.R., 1999, "Reaction of $\mathrm{Al}\left(\mathrm{C}^{\mathrm{B} u}\right)_{3}$ with Ethylene Glycol: Intermediates to Aluminum Alkoxide (Alucone) Preceramic Polymers", Chemistry of Materials, Vol. 11, No. 11, pp. 3181-3188. doi: 10.1021/ cm990284q

Okada, K., 2008, "Activation Energy of Mullitization from Various Starting Materials", Journal of the European Ceramic Society, Vol. 28, No. 2, pp. 377-382. doi: 10.1016/j.jeurceramsoc. 2007.03.015

Oliveira, T.C., Ribeiro, C.A., Brunelli, D.D., Rodrigues, L.A. and Thim, G.P., 2010, "The Kinetic of Mullite Crystallization: Effect of Water Content", Journal of Non-Crystalline Solids, Vol. 356, No. 52-54, pp. 2980-2985. doi: 10.1016/j.jnoncrysol.2010.05.078

Richardson, J.W., Pluth, J.J., Smith, J.V. and Dytrych, W.J., 1988, "Conformation of Ethylene Glycol and Phase Change in Silica Sodalite", The Journal of Physical Chemistry, Vol. 92, No. 1, pp. 243-247. doi: 10.1021/j100312a052

Rietveld, H.M., 1969, "A Profile Refinement Method for Nuclear and Magnetic Structures", Journal of Applied Crystallography, Vol. 2, pp. 65-71. doi:10.1107/S0021889869006558

Shackelford, J.F. and Doremus, R.H., 2008, "Ceramic and Glass Materials", Springer, New York, USA.

Schneider, H., Voll, D., Saruhan, B. and Schmücker, M., 1994, "Constitution of the $\gamma$-alumina Phase in Chemically Produced Mullite Precursors", Journal of the European Ceramic Society, Vol. 13, No. 5, pp. 441-448. doi: 10.1016/0955-2219(94)90022-1

Schneider, H. and Komarneni, S., 2005, "Mullite", Wiley-VCH, Weinheim, Germany.

Schneider, H., Schreuer, J. and Hildmann, B., 2008, "Structure and Properties of Mullite - A Review", Journal of the European Ceramic Society, Vol. 28, No. 2, pp. 329-344. doi: 10.1016/j. jeurceramsoc.2007.03.017

Yabuki, M., Takahashi, R., Sato, S., Sodesawa, T., and Ogura, K., 2002, "Silica-Alumina Catalysts Prepared in Sol-Gel Process of TEOS with Organic Additives", Physical Chemistry Chemical Physics, Vol. 4, No. 19, pp. 4830-4837. doi: 10.1039/B205645C 